\title{
"QUALITY" OF STANDARDIZATION OF ADMISSION TO MUNICIPAL PASSENGER TRANSPORTATION AS A CORRUPTION RISK "FILTER" IN ACTIVITY OF PUBLIC SERVANTS
}

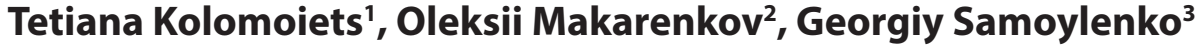

\begin{abstract}
Relevance. In terms of revising the provisions of legal regulation of relations in the field of transport with the borrowing of competitive principles of the European institutes to ensure the integration of transport into European and world transport area, with revision of models of relations between relevant public administration entities and private entities, ensuring balance of their interests, including in the context of national and supranational threats and focus on expanding the implementation of rights, freedoms and legitimate interests of the latter in the field of transport, strengthening of the principles of decentralization of power in the system of public authorities occurs, resulting in a significant increase in the number and diversity of regulatory and legal acts aimed at settling the above relations. Unfortunately, at the same time the processes of "growth" and a variety of forms of corruption in the activities of public servants, whose professional sphere is directly related to transport relations with the involvement of municipal transport, are also active. Analysis of law enforcement activities of anti-corruption entities in all its manifestations shows a fairly steady trend towards an increase in the number of detected acts of corruption committed by public servants directly related to the exercise of their authority over the procedure for admission to municipal passenger transportation. The specifics of the legislative regulation of the latter presupposes the presence of many "defects", which create the basis for variable manifestations, including illegal, of the activities of public servants with a subjective arbitrary interpretation of the latest provisions of the law. "Low-quality" regulation of the provisions of the activity of public servants to exercise power over the admission to municipal passenger transportation has a negative impact not only on the implementation of passenger rights (of various categories), but also provision of the public interest, and contributes to the formation of a national threat with a "corrosive" sign of power within administrative and territorial units, especially the country in general. An integrated approach to clarifying the problems of "municipal passenger transportation" with an emphasis on eliminating corruption risks in the activities of public servants at the stage of exercising their power to admit to transportation, which will contribute to the "quality" of such entities and will form an effective regulatory framework for the relevant component of transport in general, its effective existence, the realization of the public interest and its correlation with the interests of individuals. The purpose of the paper is the justification of the relationship of the "quality" of standardization of the procedure for admission of entities to municipal passenger transportation and corruption risks in the professional activities of public servants, which is related to this area, formulating proposals for their multi-balance ratio to minimize these risks and "qualitative" standardization of the relevant component of passenger transportation and transport relations in general based on the analysis of various sources. The objects of the article are public relations directly related to municipal passenger transportation. The subject of the article is the "quality" of standardization of relations in admission to municipal passenger transportation and its connection with corruption risks in activity of public servants connected with the specified sphere of relations. Methods of research. Both general legal and special methods of scientific cognition were used in research. As the basis, the dialectic method was used, which allowed to reveal problematic issues in dynamics; juridical and logical method allowed to form options for borrowing positive and avoiding negative experience of relevant rulemaking and law enforcement in foreign countries; forecasting and modeling were used for making proposals to
\end{abstract}

\footnotetext{
Corresponding author:

${ }^{1}$ Zaporizhzhia National University, Ukraine.

E-mail: T_deputy@ukr.net

${ }^{2}$ Zaporizhzhia National University, Ukraine.

E-mail:almak17@ukr.net

${ }^{3}$ Zaporizhzhia National University, Ukraine.

E-mail: georgesamoil1976@gmail.com
} 
strengthen "quality" of standardization of the procedure of admission to municipal passenger transportation in order to eliminate corruption risks in the activities of public servants. Results. Admission to municipal passenger transportation should be considered as a form of public procedure, the subjects of which are servants of local public authorities. Given the specifics of municipal transport in general, any activity associated with its use, objectively anticipates the risks of possible, including illegal, priority satisfaction of private interests of public servants and the interests of relatives during the exercise of the public authority, which causes "corrosion" of public authority. The procedure of admission to the relevant transportation, the "corruption freedom" of which depends on the "quality" of normalization of its provisions, is not an exception. The relationship between the "quality" of legislation and the "corruption risk" of professional activity of public servants, which is associated with the procedure of admission to the services mentioned, is interdependent (the lower the quality of legislation, the higher the risks of "corrosion" of professional activity of public servants and vice versa). In order to improve the "quality" of standardization of the procedure for admission to the transportation and minimize corruption risks in the professional activities of public servants associated with the above procedure, it is appropriate to strengthen the provisions of certainty of the content of relevant legislation, their systematization (including in the form of codification), streamlining the thematic definition series, meaningful consolidation of the principles of transparency, publicity, participation, public-private partnership, guarantee of all elements and admission procedures in general.

Key words: "quality", legislation, municipal passenger transportation, public procedure, public interest, public servants, corruption, corruption risks, transport of general use, improvement, model.

JEL Classification: D73, L91

\section{Introduction}

In terms of revising the provisions of legal regulation of relations in the field of transport with the borrowing of competitive principles of the European institutes to ensure the integration of transport into European and world transport area, with revision of models of relations between relevant public administration entities and private entities, ensuring balance of their interests, including in the context of national and supranational threats and focus on expanding the implementation of rights, freedoms and legitimate interests of the latter in the field of transport, strengthening of the principles of decentralization of power in the system of public authorities occurs, resulting in a significant increase in the number and diversity of regulatory and legal acts aimed at settling the above relations. Unfortunately, at the same time the processes of "growth" and a variety of forms of corruption in the activities of public servants, whose professional sphere is directly related to transport relations with the involvement of municipal transport, are also active. Analysis of law enforcement activities of anti-corruption entities in all its manifestations shows a fairly steady trend towards an increase in the number of detected acts of corruption committed by public servants directly related to the exercise of their authority over the procedure for admission to municipal passenger transportation. The specifics of the legislative regulation of the latter presupposes the presence of many "defects", which create the basis for variable manifestations, including illegal, of the activities of public servants with a subjective arbitrary interpretation of the latest provisions of the law. "Low-quality" regulation of the provisions of the activity of public servants to exercise power over the admission to municipal passenger transportation has a negative impact not only on the implementation of passenger rights (of various categories), but also provision of the public interest, and contributes to the formation of a national threat with a "corrosive" sign of power within administrative and territorial units, especially the country in general. An integrated approach to clarifying the problems of "municipal passenger transportation" with an emphasis on eliminating corruption risks in the activities of public servants at the stage of exercising their power to admit to transportation, which will contribute to the "quality" of such entities and will form an effective regulatory framework for the relevant component of transport in general, its effective existence, the realization of the public interest and its correlation with the interests of individuals.

\section{Analysis of recent topical resources}

The interest of legal scholars can be divided into several topic-specific areas in the general scientific search for optimal models of forming a scientific basis for the regulation of social relations directly related to municipal passenger transportation. The specificity of the subject of research determines the focus of scientists from different scientific fields, different branches of legal science, however, with increasing specialization of research in various aspects. Thus, among the most common aspects of the subject of research there is the phenomenon of a contract of carriage of passengers by municipal transport of general use, which is undoubtedly the prerogative of civilists (for example, the works by A. Yanovytska, O. Dzera, V. Borysova, O. Belianevych, 
A. Dovhert, I. Zelenskyi, O. Sadikov, Ye. Kharytonova, V. Yarotskyi, etc.), including in the context of the analysis of the issue of contract law in general. Representatives of administrative law and municipal law sciences are of no less interest, focusing on the issues of legal regulation of public administration in this area of transport relations, including in the context of decentralization of power (for example, the works by V. Beschastnyi, D. Malyshko, T. Hurzhii, M. Stotska, T. Cherniavska, A. Prysiazhniuk, S. Moskalenko, V. Kharytonova, T. Koliada, V. Ilchuk, $\mathrm{N}$. Bortnyk, etc.). Some aspects of the legal regulation of municipal passenger transportation are analyzed by representatives of financial and legal science with an emphasis on the formation and use of local budgets (for example, V. Chernadchuk, N. Huberska, etc.), labor and social law - the implementation of the right to transportation for the categories of persons entitled to "benefits", the science of economic law - business in the transport sector, etc. Studies of the problems of transport, including municipal passenger transportation, its legal regulation as an integral element of the subject of transport law, become increasingly prevalent, especially in the conditions of the upgraded vision of the system of law (for example, the works by M. Shelukhin, Yu. Zaika, B. Derevianko, S. Hrudnytska, L. Herasymchuk, O. Antoniuk, V. Vyshnevetska, etc.). It is the admission to the relevant transportation, the definition of its principles, standardization are analyzed, albeit in fragments, by representatives of various areas of public law, which is quite justified, as the specifics of transport determines its presence under any circumstances in the field of public law regulation, orientation for the realization of public interest. However, given the availability of papers directly focused on procedural issues (public procedures, administrative procedures, municipal procedures), specialized scientific works with an emphasis on the peculiarity of these procedures in relation to municipal passenger transportation (admission criteria, conditions of admission, quotas of categories of passengers entitled to benefits subject to transportation, service under certain administrative law etc.), there are quite a few of them and even the existing ones cover the mentioned issues without focusing on the "quality" of standardization and the presence of corruption risks in the professional activity of public servants, which is associated with admission to transportation (for example, the works by D. Malyshko, A. Sobakar, S. Moskalenko, N. Bortnyk, etc.). At the same time, there is a significant number of works by representatives of administrative law, criminal law science on combating corruption in general, some of its manifestations in the activities of public servants (for example, the works by O. Dudorov, M. Khavroniuk, T. Kolomoiets, S. Kushnir, O. Mykolenko, V. Kolpakov, V. Harashchuk, etc.). Unfortunately, there is no work to cover the issue of corruption risks in the activity of public servants, which is related to the field of municipal passenger transportation, including admission to them during the implementation of procedures regulated by law, which causes a gap in the scientific framework of relevant rule-making focused on improving the provisions of current legislation to enhance the "quality" of the normative principles of the above relations, which should result in order, unification of law enforcement with the elimination of preconditions for corruption by public servants.

\section{Admission to municipal passenger transportation as a type of public procedure}

Transport is a unique phenomenon that directly "permeates" the existence of the state, society, individual, ensuring both the realization of the interests of the latter (for example, freedom of movement) and the realization of public interest (transportation of persons, property, strategic connection of administrative and territorial units etc). It is "vital for everyone, and with the right mix of solutions, sustainable transport will help us to realise a better future by helping to reduce poverty while protecting the planet and driving economic growth" (Activity, 2016). Due to its polystructural, integrative nature, this specificity is inherent in all phenomena that are "related" to it, including "municipal passenger transportation". A detailed analysis of the proposed phrase contains an indication of several components of its unique resource, namely: "what", "with what", "what mode of transport". Accordingly, we can talk about: a) transportation(i.e.acertain process, and therefore about the standardized, planned, targeted, resource-provided, safe, etc. process ("what?")); b) passengers ("who?") as persons in respect of whom such transportation is carried out (different categories, including those with special needs, different ages, at different times, etc.); c) transport ("with what?"), while the title itself contains clarifications, namely "municipal transport", which simultaneously clarifies the administrative and territorial boundaries of its use, its subordination, as well as its purpose - for public use, to realize the public interest. We should also add the fact that transport is a source of increased danger, and therefore its use, and particularly for the "interests of all", for the public interest necessarily requires the presence of public law regulatory influence. Under such conditions, the subject of public authority, including local, is a monopolist in the settlement of relations directly related to the use of transport as a strategic resource, must provide such transportation independently ("light version", monopolized, typical of administrative model of regulation), or to delegate such powers to a certain subject (in "mini version", the model of mutual relations and the actual subject of transportations as close as possible on the status to the subject of public authority, or the subject linearly subordinated to it, or otherwise a dependent entity, are defined), or finally "appeal to the market", providing 
a specific approach to free access by private carriers ("hard version", which requires standardization of requirements for vehicles, carriers, transportation rules, as well as admission to such transportation). We can find another options for defining such models of relations with the participation of public authorities for the organization of municipal passenger transportation, namely: a) "communal" (Prague, Bucharest); b) "Scandinavian" (London), "competitive contracting of routes" (London, Stockholm, Copenhagen, Gifhorn); c) "French", "competitive contracting of route networks" (some cities of France, Italy, Spain, Sweden); d) "subsidiarily unregulated", "free market" with minimal public interference (Malyshko, 2017). In a market economy, competitive principles of relations in general, the latest "version" of the legal regulation of municipal passenger transport seems fair, relevant, focused on providing "the best for less". And this is quite justified only if there are "quality" standardization (clear, transparent, defined, with no grounds for discretion, for arbitrary, subjective interpretation of the law and its application) of the procedure for admission to such transportations and compliance with the relevant requirements during transportation. On the one hand, the first two "versions" are "traditional", "ordinary", "stable", "less comfortable" in the context of the public interest in transportation, but on the other hand, they indicate "more corruption riskiness" because they eliminate any initiative, participativity, transparency, "the desire to offer better, comfortable with lower costs", they can be called conditionally "cliched". Admission to transportation under such "versions" is conditional, formal, "cliched" and more "collision" (the subject carries out, controls, reports and in case of deviations - hides independently). The last "version" is dynamic, "live", "flexible", "mixed", provides "external" influence, and therefore more transparent, with the possibility to modify individual elements, variable in the implementation process and so on. Admitting individuals or anyone in general to tender for transportation actually regularizes competition, the pursuit of "better quality", which certainly deserves approval and implementation, but at the same time requires detailed standardization of the definition of the "best" carrier and its admission to transportation. When introducing tender for admission of persons to the relevant transportation (as the most common procedure in the world), the subject of public authority should be aware of the following elements: the expediency of its detailed standardization (to eliminate "defects" of interpretation and application of legal requirements by entities with different levels of legal culture, legal education); target orientation (the "best" carrier, effective realization of publicinterest), as "ensuring the realization of the rights of persons and preventing their violation" (Administratyvna protsedura, p. 7), the occurrence of "external" consequences that violate the rights and responsibilities of persons who are "outside the system of public administration" (Administratyvna protsedura, p. 7); by-law explicitation (local rule-making taking into account the peculiarities of the administrative and territorial unit, population, migration processes, etc.); security; legal means support, formal consolidation of the result (as a kind of administrative act); urgent burden (limited in time because it requires realization of public interest); indisputability (solution of the "positive" case). The presence of these features, typical for the public procedure, suggests that the procedure for admission to municipal passenger transportation is one of the varieties of such a procedure.

\section{Corruption risks for public servants during the procedure of admission to municipal passenger transportation}

The relevant admission procedure should be considered with an emphasis on the presence of corruption risks for public servants when using any of the above "versions" of the relationship. However, for the first two there will be many of them, they will be "more relief" because they provide direct "immersion" of subjects in purely public relations, minimization of "external" intervention, expanded opportunities for less detailed internal regulation of principles, increased latency of possible violations and their consequences, intrasystemic subjective "opposite" unity, etc. However, the third "version", although provides for the introduction of competitive principles, expands the grounds for "external" intervention, public participation, transparency, etc., also does not eliminate corruption risks in the activities of public servants whose professional field is related to the admission procedure to the transportation mentioned. Despite the prevalence of such a procedure in many countries around the world, it is the "quality" of standardization of its principles that determines the "corruption riskiness" of the activities of public servants in this area of relations and the development of this area in general. Summarizing the relevant experience, we can conditionally identify several "basic" corruption risks, the presence or absence of which is directly related to the "quality" of legislation. Among them there are: a) collision in regulation of the principles of implementation of the powers of local public authorities to admit persons to these transportations in the legislation on transport, modes of transport and the legal status of these public authorities. The model with a detailed list of powers in both the "basic" legislation on local public authorities and the "basic" legislation on transport ("duplication" of provisions) is the "perfect" one. Such a model is typical for most European countries, but there is also a model with fixing the principles of discretionary powers of these entities in the relevant field and different provisions on the powers of these bodies in this area (for example, Ukraine), which is a prerequisite for 
subjective approach to the arbitrary interpretation of the provisions of the law or different solutions to the collision of legal requirements. Describing discretion as a "corruption risk" in the activities of any public servant, Cesar Queiroz and Alex Visser, referring to the work by Robert E. Klitgaard, reasonably defined their place in the formation of corruption, namely: "corruption = $=$ monopoly + discretion - accountability" (Klitgard, 1988), (Corruption, 2001), which was justified for the scope of these transportation and the activities of public servants directly related to the latter. Absolute standardization of the relevant powers of local public authorities in legislative acts that determine their status, as well as in transport legislation, the provisions of which duplicate these powers, eliminate the preconditions for "corrosive" interpretation and application of relevant provisions; b) a somewhat formal and residual approach to the use of tender as a procedure for admission to these services, which should be considered as a kind of "comprehensive" basis for possible acts of corruption of public servants in the exercise of their powers. Unfortunately, the analysis of the legislation of different countries of the world shows different approaches to settling the principles of this tender procedure: from the most detailed (for example, Germany, Poland, France), detailed (for example, the Czech Republic, Hungary) and settled in general (for example, Ukraine), with commensurate "corrosion" threats to local public authorities. Among the "problematic" issues of procedure regulation there can be distinguished:

1) defects of the subject element, namely the absent or generalized approach to determining the composition of the tender commission (working body), which "accompanies" such a procedure, makes the final decision on which the act of governance is issued. Most of the provisions on "public admission", "public participation", but the criteria for selecting members of the tender commission, including members of the public are "normatively indefinite". In particular, in Ukraine, it is envisaged that at least $50 \%$ of the tender commission should be formed by representatives of public organizations whose activities are related to the field of transport (Postanova, 2008). At first glance, the provision is logical, reasonable, it fixes the principles of public participation. Unfortunately, the analysis of law enforcement practice shows the "defects in content" of this provision, because it is unclear which public organizations can form the composition of the tender commission, because the concept of "transport" is too broad, and therefore there can be different public organizations, including those concerning different modes of transport. Public servants "involved" in the formation of the tender commission, in fact, have "ample opportunities" to adjust its composition, interpret these regulations differently. In addition, it is unclear why the "public" element of the tender commission should be equal to " $50 \%+$ " given that the commission should include representatives of many bodies authorized to exercise special powers in the field of urban passenger transportation (traffic safety, environmental safety, resource provision, etc.). The ratio should be justified so that the result of the admission is effective, and transportation - high-performance, can promote the realization of the public interest, including in the face of extreme threats. That is why in order to eliminate any arbitrary manifestations of interpretation and application of its provisions, participation of "fake", "one-day" public organizations, agreements between business entities on the distribution of "procedures for admission to the transport sector", the ratio of participants, as well as the criteria for their selection, should be clearly defined in legislation.

2) defects in the standardization of the admission procedure itself, because both the monopoly of the public authority on the organization of the relevant transportation, and a purely "commercial", "private" subjective element of service have threats to the efficiency and effectiveness of such transportation (Kenny, 2009), including due to the "redistribution of the transport sphere between several entities" (Sieber). It is logical to establish the principles of mandatory involvement of both private and public entities for the organization of such transportation, the introduction of "mixed" municipal passenger transportation (for example, the experience of Spain, Sweden, Germany, Australia) (Germa Bel, Jordi Rosell), the role and importance of which significantly increase in the context of national, supranational threats (for example, in the context of the COVID-2019 pandemic). It is important to ensure transparency, accessibility, certainty and clarity of the terms of the tender, the procedure of the tender, its result, guaranteed implementation of the latter. Under such conditions, it is necessary to realize that it is the "defect" of the standardization of these provisions that provides the maximum grounds for possible illegal action by a public servant whose professional activity is related to transport including with admission to the above transportation. Niklas Sieber rightly draws attention to the need to ensure "independent audit of the terms of the tender, transparency of information about the event, accessibility, clarity of information, free access to it, free circulation of information, control, reporting" (Sieber). Charles Kenny singles out almost similar problems, noting that their elimination will help to overcome "corruption in transport", and therefore among the important prevention tools there are: public orientation, control, transparency through public participation in tenders and public control of tender documents, independent audit and public-private anticorruption cooperation" (Kenny, 2009). The specified provisions are acceptable to eliminate "corrosion" in the procedure of admission to municipal passenger transportation in different countries, because there is: the practice of "formal" admission to the tender 
without an independent audit of its conditions (mainly in Eastern European countries), limited informing (for example, release of information only in the print media (sometimes even without specifying media) (for example, in Latin American countries) but not on the official websites of authorized bodies), untimely informing about the stages of the procedure, "closed" mode of the tender commission and stretched period to sign the protocol of its meeting and submit to the subject of public authority to adopt an act of governance (for example, in the countries of South Asia, Africa); all this creates "barriers" to control both the procedure and its result. In fact, the "red flags" (Kenny, 2009), or identifiers of corruption risks in the public activity of employees, which is related to the admission to municipal passenger transportation, are outlined: a) the absence (limitation) of public admission to the tender information; $b$ ) nontransparency (discrimination) of criteria for selection of members of the tender commission; c) incomplete information about the procedure, its elements; d) lack of independent audit of tender conditions; e) non-transparency (barrier) of public participation; f) "closed" tender procedure and final decisionmaking; g) the absence of "barriers" for the monopoly participation of several entities; h) long terms for registration of the decision of the tender commission, announcement of results and acceptance of the act of governance. The "defect" of enshrining these provisions actually forms the preconditions for possible arbitrary, subjectively justified actions of public servants, whose professional activity is associated with admission to municipal passenger transportation, taking into account the priority of the realization of their private interests, the interests of their relatives, which threatens the realization and protection of public interests, contributes to the "corrosion" of public authority. Elimination of such identifiers of corruption risks will facilitate the improvement of the procedure of admission to the specified transportations, its transparency, certainty, "target purity" of participation of subjects, with gradual normative consolidation of ISO 37001: 2016 procedures (ISO 37001:2016. Anti-bribery management system - Requirements with guidance for use) (Antibribery, 2016), but also solving a range of other issues, taking into account the specifics of the sphere of relations, such as: environmental safety through "environmentally friendly" vehicles, transportation of passengers with special needs, freedom of movement, which must be facilitated by public authorities, taking into account the relevant categories of persons, the popularity of municipal passenger routes, financial revenues to local budgets from this type of activity with the maximum implementation of automated systems, modernization of transport infrastructure with increased comfort, attractiveness, simplification of use, providing municipal passenger transportation adhering to the requirements of national and supranational threats, etc.

\section{5. "Quality" of standardization of the principles of admission to municipal passenger transportation as an effective condition for preventing corruption in the professional activity of public servants}

The "quality" of standardization is traditionally considered in legal science in terms of "quality of rule-making" as an activity focused on "development, consideration, adoption and official promulgation of regulations determined by a certain procedure" (Zahalna, 2020) and as the "quality of the result of such rule-making" or "quality of legislation" in the broadest sense, covering all regulations designed for the relevant sphere of public relations (Parkhomenko, 2008). In this paper, the "quality" of the legislation should be defined as already existing legislation that regulates the sphere of relations directly related to the admission to transportation with participation of public servants. The specificity of the sphere determines the specificity of the legislation (especially taking into account the peculiarities of the administrative and territorial division of the country, territorial organization of power), and hence the requirements for "quality", mainly in the context of growth and diversification of "external" threats which affects its interpretation and application, further forming the basis for the "corrosion" of public authority. The subject of research is no exception. In order to prevent these negative phenomena, their consequences, it is appropriate: a) to systematize regulations that define the powers of all public entities in the field of transport, including those on admission to municipal transportation, in a single codified legal act (for example, the Transport Code as in the USA); b) to coordinate the provisions of this act with the content of legislative (possibly systematized) acts fixing the legal status of local public authorities; c) to enshrine the provisions in the section "Procedures in the activity of management entities in the field of transport" of the above codified legal act and to define the admission as a kind of public procedure; d) to detail the procedural principles of admission to the maximum using absolutely defined rules (without evaluative provisions, "open" lists, etc.); e) to fix the provisions on the formation of the tender commission with mandatory representation of not less than $40 \%$ of the personnel of public organizations whose statutory activities are directly related to the specified type of activity of the relevant mode of transport in the administrative and territorial unit; to provide mandatory external audit of tender conditions; to ensure mandatory participation of public and private entities in the tender providing public-private partnership in various forms (adopting the experience of Great Britain and Portugal); to release the terms of the competition, its stages, results on the official website of the public authority, whose powers include the organization and implementation of the admission procedure; to 
conduct an open tender and cover its results promptly, to prepare the act of governance; to control over the implementation of the result of admission and response in case of deviations from these requirements. The "quality" of the standardization will help to minimize the subjective arbitrary manifestation of the will of the public servant regarding the admission to the specified transportations, and hence his or her opportunities for any, including illegal, actions focused on the priority of satisfying their private interests and the interests of their relatives, and hence the "corrosion" of public authority.

\section{Conclusions}

Admission to municipal passenger transportation should be considered as a form of public procedure, the subjects of which are servants of local public authorities. Given the specifics of municipal transport, any activity associated with its use, objectively anticipates the risks of possible, including illegal, priority satisfaction of private interests of public servants and their relatives causing the "corrosion" of public authority in the exercise of the public powers provided. The procedure of admission to the transportation, the "corruption freedom" of which depends on the "quality" of normalization of its provisions, is not an exception. The relationship between the "quality" of legislation and the "corruption risk" of professional activity of public servants, which is related to the procedure of admission to the services mentioned, is interdependent (the lower the quality of legislation, the higher the risks of "corrosion" of professional activity of public servants and vice versa). In order to improve the "quality" of standardization of the procedure for admission to the transportation and minimize corruption risks in the professional activities of public servants associated with the above procedure, it is appropriate to strengthen the provisions of certainty of the content of relevant legislation, their systematization (including in the form of codification), streamlining the thematic definition series, meaningful consolidation of the principles of transparency, publicity, participation, public-private partnership, guarantee of all elements and admission procedures in general.

\section{References:}

Activity report 2014 and 2015/ International Association of Public Transport. Bruxelles: UITP. 2016, 60 p.

Malyshko, D. V. (2017). Administratyvno-pravove rehuliuvannia u haluzi munitsypalnoho transportu v Ukraini: Dysertatsiia k.yu.n.: 12.00.07 [Administrative and legal regulation in the sphere of municipal transport in Ukraine: Dissertation of the Cand.Sc. (Law): 12.00.07]. Zaporizhzhia: ZNU.

Boiko, I. V., Zyma, O. T., \& Soloviova, O. M. (2017). Administratyvna protsedura: konspekt lektsii [Administrative procedure: lecture notes]. Kharkiv: Pravo.

Klitgaard, Robert E. (1988). Controlling Corruption. Berkeley: University of California Press.

Corruption, Transport Infrastructure Stock and Economic Development by Cesar Queiroz and Alex Visser. World Bank. Infrastructure Forum. Washington, D.C. May 2-11, 2001. Available at: http:// citeseerx.ist.psu.edu/viewdoc/ download? doi=10.1.1.582.3165Lrep=rep1Itype $=$ pdf

Pro zatverdzhennia Poriadku provedennia konkursu z perevezennia pasazhyriv na avtobusnomy marshruti zahalnoho korystuvannia: Postanova Kabinetu Ministriv Ukrainy vid 03 hrudnia 2008 roku № 1081 [On Approval of the Tender Procedure for Passenger Transportation using Bus Route of General Use: Resolution of the Cabinet of Ministers of Ukraine No 1081 dated December 03, 2008]. Available at: http://zakon.rada.gov.ua/laws/ show/1081-2008-\%DO\%BF\#Test

Kenny, Charles (2009). Transport Construction, Corruption and Developing Countries, Transport Reviews, 29:1, 21-41.

Sieber, Niklas. Fighting Corruption in Road Transport Sector. 10. Lessons for Developing Countries Sustainable Urban Transport Technical Document №10. Available at: http://www.researchgate.net/publication/301232311Corruption-in-Transport

Germa Bel and Jordi Rosell. The role of transaction cost on mixed delivery analysis: evidence from the Barcelone local bus system. Available at: http://dialnet.unirioja.es/descarda/articulo/5187615.pdf

Kenny, C. (2006). Measuring and Reducing the Impact of Corruption in Infrastructure. World Bank Policy Research Working Paper. № 4099. Washington DC.

ISO 37001:2016. Anti-bribery management system - Requirements with guidance for use. Available at: http://www.iso.org/standard/65034/html

Petryshyn, O. V., Lukianov, D. V., Maksymov, S. I., Smorodynskyi, V. S. et al. (2020). Zahalna teoriia prava: pidruchnyk [General theory of law: textbook]. Kharkiv: Pravo.

Parkhomenko, N. M. (2008). Dzherela prava: problem teorii ta metodolohii [Sources of law: problems of theory and methodology]. Kyiv: TOV Vydavnytstvo "Iurydychna dumka". 